\title{
Diversity, Structure and Dynamics of a Mangrove Forest: a Case Study
}

\author{
Suresh S. HEBBALALU ${ }^{1}$, Dattatray M. BHAT ${ }^{1}$, Ravindranath H. NIJAVALLI ${ }^{2}$, \\ Sukumar RAMAN ${ }^{1 *}$
}

\author{
${ }^{1}$ Center for Ecological Sciences, Indian Institute of Science, Bangalore 560012, India; rsuku@ces.iisc.ernet.in (*corresponding author) \\ ${ }^{2}$ Center for Sustainable Technologies, Indian Institute of Science, Bangalore 560012, India
}

\begin{abstract}
The intertidal vegetation along tropical and subtropical coast is defined as mangrove vegetation. India has a long coast line measuring $7516 \mathrm{~km}$. The ecology of mangrove forest is relatively less studied. Mangrove systems are known to be one of the most productive systems in the world. The study aimed to estimate the carbon sequestration potential of a relatively protected sacred grove along the western coast of India, in Kagekanu, Kumta, Karnataka. One hectare permanent plot was established, with all woody stems $>1 \mathrm{~cm}$ dbh (diameter at breast height), which were marked and identified. Repeated measurements were made to register the growth and other parameters. Allometric equation was used to estimate the biomass, out of which $50 \%$ was considered as carbon content. A total of 1100 stems $>1 \mathrm{~cm} \mathrm{dbh}$, belonging to 4 species, were enumerated. There was an overall decline of $13.9 \%$ stems during the study period. Mean mortality rate was found to be $5.83 \pm 1.85 \%$ and there was no recruitment. The biomass increased from 155.53 tons/ha to 164.28 tons/ha. There was a net gain of 4.38 tons. Avicinnia officinalis was found to contribute significantly to carbon sequestration.
\end{abstract}

Keywords: Avicinnia officinalis, biomass, carbon sequestration, growth, mortality, recruitment, Rhizophora mucronata

\section{Introduction}

Mangrove forests have attracted attention of humans historically by their special adaptation for surroundings, their economical utilities and their ecology (Lugo and Snedekar, 1974). The intertidal forested vegetation in tropical estuarine zones is defined as "mangrove" (Mooney et al., 1995; Valiela et al., 2001); they consist of salt tolerant species with complex dynamics (Lugo and Snedekar, 1974; Tomlinson, 1986; Duke et al. 1998) and are estimated to cover about $240 \times 103 \mathrm{~km}^{2}$ area (Lugo et al., 1990; Mandal and Naskar, 2008). Valiela et al. (2001) found that at least $35 \%$ of the mangrove habitats were lost during the last two decades. Giri et al. (2008) opine that mangrove forests in India and Bangladesh have remained largely unchanged during 1975-2005, and even more, it gained a small percentage area. Although mangrove forests cover small geographical area, they have a unique and significant contribution to the carbon geochemistry (Mitra et al., 2011) and provide a wide range of ecosystem services (Badola and Hussain, 2005; Donato et al., 2011). The floristics of mangrove forests has been reviewed globally (Duke et al.,
1998) and at local scale, for example Sundarbans (Gopal and Chauhan, 2006), but the studies on the patterns of diversity, structure and dynamics of mangrove are scarce. The land forests including tropical aseasonal (Lee et al 2002), seasonal dry (Mc Shea et al. 2011), and temperate forests, have been extensively studied for several ecological aspects. The large consortium of large plots network coordinated by Center for Tropical Forest Science (CTFS) has been monitoring tropical forests for a long time (Condit, 1998). There are other networks, such as "rainfor", that monitor forests. But with all this, there is no such organized effort to monitor mangrove forests.

India has a long coast line of $7516 \mathrm{~km}$, including island territories. Recent estimation of mangrove forest cover is of $4639 \mathrm{~km}^{2}$, which is about $3 \%$ of the global mangrove forest area (FSI, 2011), including in this surface also Sundarbans, the land shared between India and Bangladesh, which is probably the largest wet land in the world (Gopal and Chauhan, 2006). Indian mangroves have been classified as "tidal wetlands, woody vegetation", under a hierarchical system of classification that considers factors such as location, salinity, physiognomy and duration of flooding (Gopal and Sah, 1995). Indian mangrove vegetation has 
three distinct zones: 1 . East coast habitats, having a coast line of $2700 \mathrm{~km}$, facing the Bay of Bengal; 2. West coast habitats, having a coast line of $3000 \mathrm{~km}$, facing the Arabian sea; 3. Island territories with $1816 \mathrm{~km}$ of coast line (Mandal and Naskar, 2008). Mandal and Naskar (2008) also recognized three habitat types with the Indian mangroves, which include: a. Deltaic mangrove habitat (east coast mangrove and gulfs of Gujarat), b. Coastal mangrove habitat (west coast mangroves) and c. Island mangrove habitat (Lakshadweep, Andaman and Nicobar islands). Characteristics and status of mangroves along the Indian coast have been reviewed by Selvam (2003). Studies in Indian mangroves have been along the lines of documenting biodiversity (Gopal and Chauhan, 2006), biomass (Mitra et al., 2011), nutrient dynamics (Kumar et al., 2011) and other conservation aspects, such as review of status (Jagtap et al., 1993; Gopal and Chouhan, 2006). Biodiversity studies in mangrove forests have focused on describing different species of both true mangrove and associates of mangrove formations in Sundarbans (Joshi and Ghose, 2003; Gopal and Chouhan, 2006), Godavari delta (Azariah et al., 1992), Bidarkarnika (Upadhyay and Mishra, 2008) or Andamans (Singh et al., 1987). There are hardly any studies on the quantitative aspects of vegetation diversity and growth rates on mangrove species, based on repeated stem measurements.

This paper describes the diversity and structure in a onehectare permanent vegetation plot of a mature mangrove sacred grove along the western coast of Karnataka. The present study describes the dynamics of the forest, including population changes, demographical changes based on size class distribution, patterns of mortality, growth and carbon sequestration over a period of three years. This is probably the first permanent plot based systematic and an innovative and elaborate study on the mangrove forest in India.

\section{Study area}

This study was undertaken in Uttara Kannada district (14 $63^{\circ} \mathrm{N}$ Lat and $74^{\circ} 81^{\prime}$ E Long) of Karnataka state,

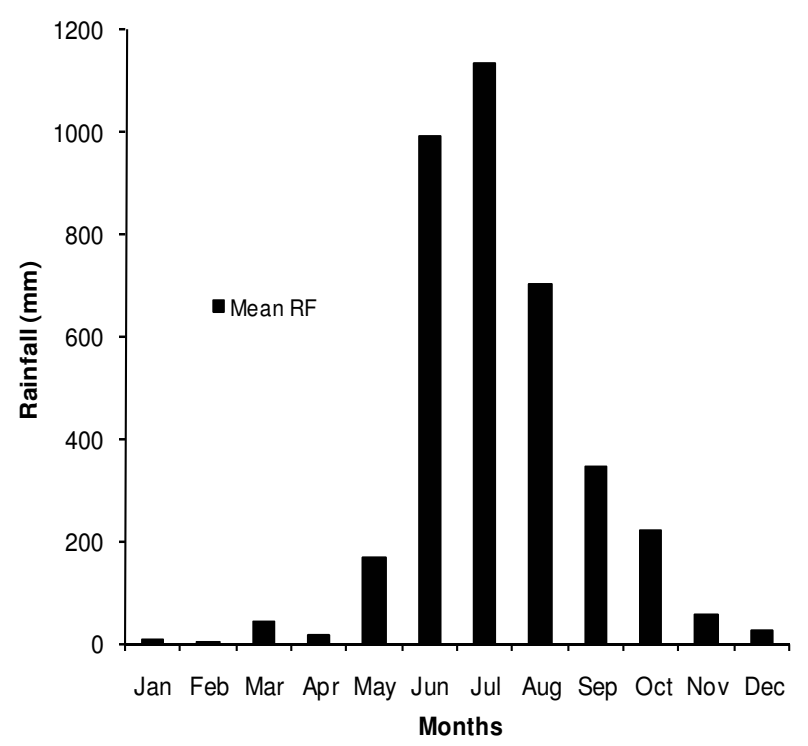

Fig. 1. Rainfall pattern in the study area (Kumta). Data from District met office, Karwar, for the period of 1990-2010 south India. Uttara Kannda is characterized by undulating terrain with fertile valleys. There is a considerable variation in the altitude, ranging from sea level to as high as 1000 meters ASL. Rainfall is mainly from the southwest monsoon, which is active from June to September. Mean annual rainfall during $1990-2010$ is $3629.6 \pm 521 \mathrm{~mm}$, with June and July being the rainiest months (Fig. 1). The vegetation varies from tropical seasonal evergreen forests and its variants towards the west to moist deciduous forests on the eastern part (Pascal, 1986). Administratively, the forests in the district are classified into the following categories: a. Reserve forest (exclusively under state control and highly regulated), b. Minor forests (extraction of biomass and fuel wood is allowed to meet the demands of people) and c. Leaf manure forests, or locally called " Soppina betas" (forest area allotted to areca nut farmers under certain privileges for extraction of leaf and dry wood). Further, detailed description of the study area can be found in Daniels (1989) and Bhat et al. (2011). In Uttara Kannada district mangrove patches are seen in estuarine zones of important westward flowing rivers such as Kali, Bedthi, Aghanashini, Sharavathi and Vektapura. Mangroves are also present along the estuaries of small creeks and rivulets. Among these, Kali and Aghanashini estuaries support larger isolated mangrove patches. River Aghanashini runs in thick forests and amid cultivated lands, mainly paddy and Areca orchards, forms two waterfalls, covers a total distance of about $121 \mathrm{~km}$ before joining Arabian sea at Tadri and Aghanashini villages. The estuary is $13 \mathrm{~km}$ long and $2-6 \mathrm{~km}$ broad. This is the only river in Uttara Kannada district so far not dammed and with no major townships and industries polluting the water (Gadgil et al. 1993). Therefore, it is supposed to be least polluted. Before joining the sea, it forms many islands in the estuarine zone, varying in area. These islands are locally called by names such as Masurkurve, Gunda, Kekanakodi, Keppekuve, Tanneerahonda, Chowlihonda. Among these, Masurkuve is the largest, comprising about 32 ha. Though part of the land area of the island is cultivated by the local farmers, there is a good mangrove patch along the fringe. This patch is conserved and protected over many years in the name of a deity 'Bobbrudevaru', which is housed in a temple in the island. On the account of this, local community considers the patch as sacred and do not extract from this mangrove patch for personal use. However, collection and use of dead and fallen wood is allowed for performing religious rituals for the deity. This particular forest patch is called Kagekanu ( $14^{\circ} 42^{\prime} \mathrm{N}$ Lat and $74^{\circ} 40^{\prime} \mathrm{E}$ Long). Majority of the islands are used for prawn culture after the harvest of the paddy crop.

\section{Material and Methods}

We established one-hectare (100 x 100 meters $)$ permanent plot in the sacred groove. Caution was taken in laying the plot to avoid edge effect. For easy enumeration we temporarily divided this plot into smaller blocks of 20 X 20 meters, by laying ropes. Within these smaller blocks, all woody individuals $>1.0 \mathrm{~cm} \mathrm{DBH}$ (diameter at breast height) were enumerated for species, measured for size and marked with a unique tag number. Point of measurement was marked with paint for successive measurements. Multiple stems were given the same number and measured 
302

for size. Any deformity on the stems, such as stem breakage, bark stripped, top broken and branches pulled, were noted.

Sizes of surviving stems were measured annually at the same point of measurement. Dead stems were noted, and recruitment of new stems of $1.0 \mathrm{~cm} \mathrm{DBH}$ was also marked. Sizes of the largest stems were considered for growth analysis for individuals with multiple stems. All stems were included in basal area estimation. Mortality rate was estimated as the proportion of dead stems with respect to surviving stems and expressed as percentage. Recruitment was defined as appearance of new stems $>1 \mathrm{~cm}$ DBH in accordance with CTFS protocols (Condit, 1998). Growth rate was calculated as difference in size between census periods over time elapsed between census period.

Above ground biomass (AGB) was calculated using allometric equation based on diameter, developed by Chave et al. (2005) for wet mangrove forest patches:

$\mathrm{AGB}=\rho^{*} \exp \left(-1.349+1.980^{*} \ln (\mathrm{D})+0.207^{*}(\ln (\mathrm{D}))^{\wedge} 2-\right.$ $\left.0.0281(\ln (\mathrm{D}))^{\wedge} 3\right)$,

where $\rho=$ wood specific gravity $\left(\mathrm{grams} / \mathrm{cm}^{3}\right), \ln =$ natural logarithm and $\mathrm{D}=\mathrm{dbh}(\mathrm{cm})$.

There are several allometric equations developed for the estimation of AGB (Chave et al., 2005; Brown et al., 1989; FRI, 1970). The current equation is precise and also used in estimation of biomass by CTFS global network of permanent forest dynamics plots (Chave et al., 2005). A universal mean value of 0.6 was used as wood specific gravity, as many mangrove species specific values are not available. $50 \%$ of AGB was considered as $\mathrm{C}$ stocks, according to IPCC standards.

\section{Results}

One-hectare permanent plot at Kagekanu had 1100 individuals $>1.0 \mathrm{~cm}$ dbh (diameter at breast height) belonging to 4 species. Rhizophora mucronata (Rhizophoraceae) was the dominant specie, with 368 individuals, followed by Avicinnia officnalis (Verbenaceae, 273 individuals), Sonneratia alba (Sonnaratiaceae, 233 individuals) and Kandelia kandel (Rhizophoraceae, 233 individuals). Rhizophora mucronata and Avicinnia officinalis accounts for more than $58 \%$ of the stand composition (Tab. 1). Vegetation diversity of the plot was low. The probability

Tab. 1. Abundances of different species in the Kagekanu permanent vegetation plot

\begin{tabular}{cccc}
\hline $\begin{array}{c}\text { Species } \\
\text { (Family) }\end{array}$ & $\begin{array}{c}\text { Number of } \\
\text { Individuals }\end{array}$ & $\begin{array}{c}\text { Rel. } \\
\text { Abundance } \\
(\%)\end{array}$ & $\begin{array}{c}\text { Cum. } \\
\text { Abundance } \\
(\%)\end{array}$ \\
\hline $\begin{array}{c}\text { Rhizhophora } \\
\text { mucronata } \\
\text { (Rhizhophoraceae) }\end{array}$ & 368 & 33.45 & 33.45 \\
$\begin{array}{c}\text { Avicinnia } \\
\text { officinalis } \\
\text { (Verbenaceae) }\end{array}$ & 273 & 24.81 & 58.27 \\
$\begin{array}{c}\text { Sonnaratia alba } \\
\text { (Sonnaratiacae) }\end{array}$ & 233 & 21.18 & 79.45 \\
$\begin{array}{c}\text { Kandlia kandel } \\
\text { (Rhizhophoraceae) }\end{array}$ & 226 & 20.54 & 100 \\
\hline
\end{tabular}

of picking two individuals (Simpson's index) though was relatively high (0.73), while the heterogeneity index (Shannon-Weiner's H) was low (1.36). Non-parametric

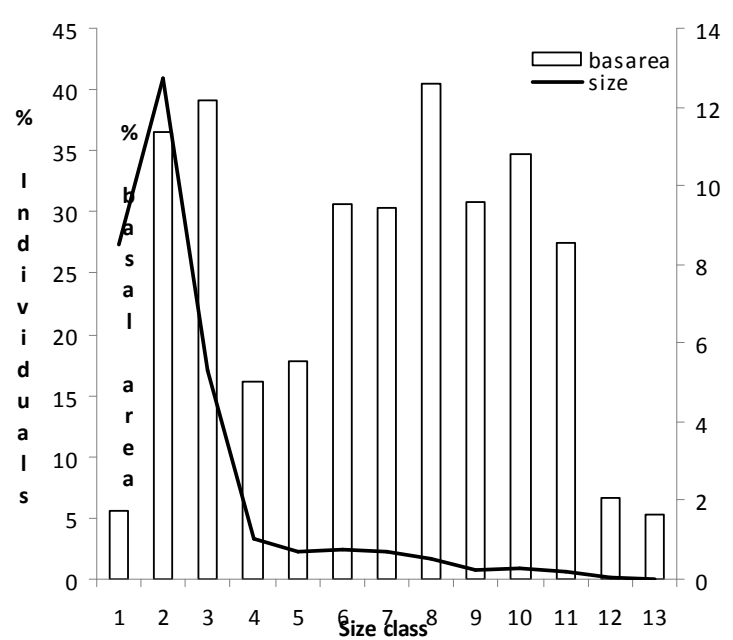

Fig. 2. Size class distribution of individuals and basal area in Kagekanu permanent vegetation plot

estimation of species diversity, Fisher's alpha, was also very low (0.52). The distribution of individuals among various species was uniform, as shown by the high evenness index (0.98).

Size class distribution of individuals followed the typical inverted "J" shape (Fig. 2). There was a large concentration of individuals in $5-10 \mathrm{~cm}$ size class. Over $62 \%$ of the individuals were in $0-10 \mathrm{~cm}$ size class (Fig. 2). Among species, Avicinnia had more or less a uniform distribution of individuals in each size class (Fig. 3) and was significantly

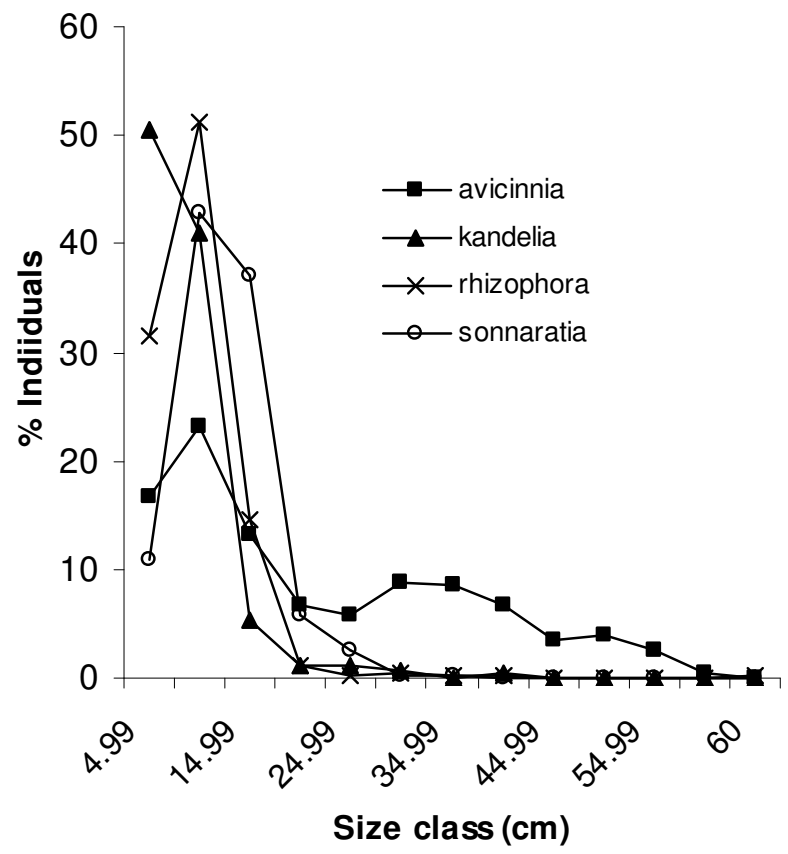

Fig. 3. Distribution of individuals in various size classes

different from all species (KS test, $\mathrm{p}>0.05$ ). Other species did not show significant difference among themselves (KS test NS). There were 339 stems (30.9\%) that had multiple stems. Population of Avicinnia officinalis had much larger stems with mean $\mathrm{dbh}$ of $21.4 \pm 15 \mathrm{~cm}$, followed by 
Sonnaratia alba $(10.6 \pm 4.3 \mathrm{~cm})$, Rhizophora mucronata $(7.1 \pm 4.4 \mathrm{~cm})$ and Kandelia kandel $(6.1 \pm 4.5 \mathrm{~cm})$.

Total basal area of the one hectare plot was $24.4 \mathrm{~m}^{2}$. Avicinnia officinalis accounts for $69.5 \%\left(16.9 \mathrm{~m}^{2}\right)$ of the total basal area, followed by Rhizophra mucronata (14.1\%, $\left.3.4 \mathrm{~m}^{2}\right)$, Sonnaratia alba $\left(11.5 \%, 2.8 \mathrm{~m}^{2}\right)$ and Kandelia kandel $\left(4.7 \%, 1.1 \mathrm{~m}^{2}\right)$. Basal area was more or less uniformly distributed across size classes and did not show concentration in higher size class as observed with several other mature forests (Fig. 2). Total biomass of the plot was 155.53 tons. Avicinnia officinalis accounted for $77.4 \%$ of total biomass, followed by Rhizophora mucronata (10.8\%), Sonnaratia alba (8.3\%) and Kandelia kandel (4.1\%).

\section{Dynamics of the forest}

Population change

There was a decline of the population from 1100 individuals in 2008 to 971 in 2011, resulting in an overall decline of $13.9 \%$. All species have shown decline, but Kandelia kandel had the maximum decline of $16.5 \%$ (Tab. 2). Mean decline observed in all species was in the range of $4.27 \%$ to $5.73 \%$ (Tab. 2). There was a major decline in the lower size classes (Tab. 3). However, there is a positive trend in higher size classes, as a result of growth from smaller size class.

\section{Mortality and recruitment}

Mean mortality rate of the community was $5.83 \pm 1.85 \%$ (range $=4.27 \%-7.88 \%, \mathrm{~N}=3$ ). Among the different species, Avicinnia officinalis had a mean rate of $4.95 \pm 1.62 \%$, Kandelia kandel had 6.79 $\pm 3.06 \%$, Rhizophora mucronata had $5.13 \pm 2.33 \%$ and Sonnaratia alba had $7.10 \pm 2.02 \%$ mortality rates. There was no significant difference in

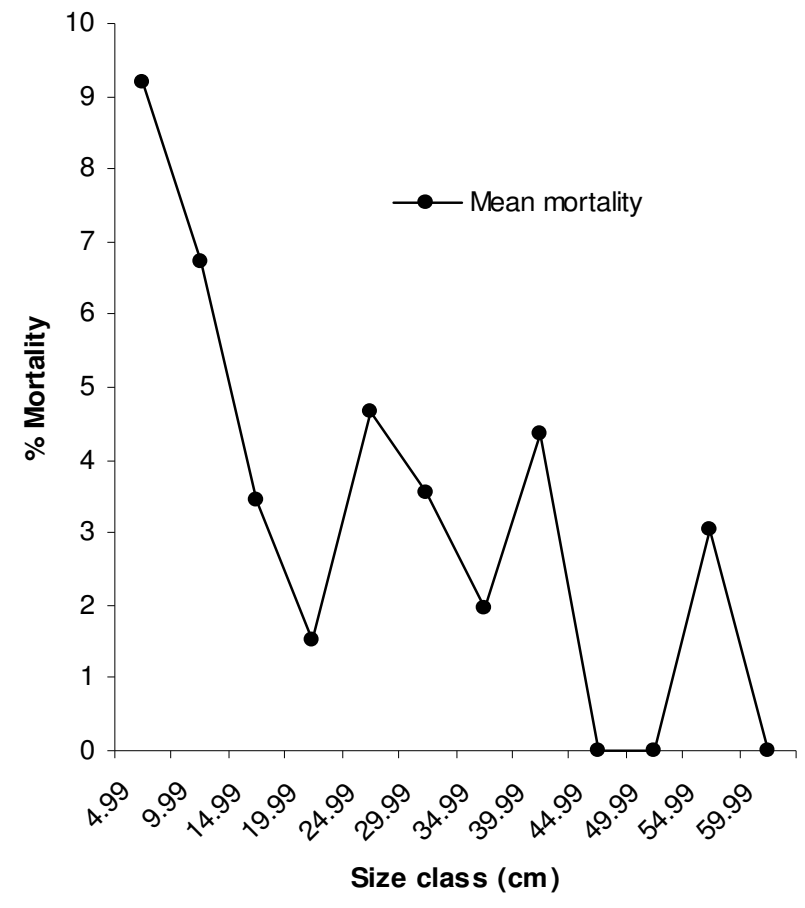

Fig. 4. Size class specific mortality observed in Kagekanu permanent plot

mortality rates between species ( $\mathrm{t}$ test, $\mathrm{NS}$ ).

There was a declining trend in mortality rates with increasing sizes (Fig. 4); however, there were elevated mortality rates in the size classes of $20-25 \mathrm{~cm}, 35-40 \mathrm{~cm}, 50$ $55 \mathrm{~cm}$ dbh (Fig. 4). Mean mortality rate for stems $<30 \mathrm{~cm}$

Tab. 2. Population changes observed in Kagekanu permanent vegetation plot

\begin{tabular}{|c|c|c|c|c|}
\hline $\begin{array}{c}\text { Species } \\
\text { (Family) } \\
\end{array}$ & $\begin{array}{c}\text { Percent change } \\
(2008-2009)(\text { N 2008) }\end{array}$ & $\begin{array}{c}\text { Percent change } \\
(2009-2010)(\text { N 2009) }\end{array}$ & $\begin{array}{c}\text { Percent change } \\
(2010-2011)(\text { N 2010) }\end{array}$ & $\begin{array}{c}\text { Percent change } \\
(2009-2011)(\mathrm{N} 2011)\end{array}$ \\
\hline $\begin{array}{c}\text { Rhizhophora mucronata } \\
\text { (Rhizhophoraceae) }\end{array}$ & $-5.70(368)$ & $-4.32(347)$ & $-3.01(332)$ & $-12.5(322)$ \\
\hline $\begin{array}{c}\text { Avicinnia officinalis } \\
\text { (Verbenaceae) }\end{array}$ & $2.56(273)$ & $-12.5(280)$ & $-2.85(245)$ & $-12.8(238)$ \\
\hline $\begin{array}{l}\text { Sonnaratia alba } \\
\text { (Sonnaratiacae) }\end{array}$ & $-8.58(233)$ & $-6.10(213)$ & $-1.00(200)$ & $-15.02(198)$ \\
\hline $\begin{array}{c}\text { Kandlia kandel } \\
\text { (Rhizhophoraceae) }\end{array}$ & $-5.75(226)$ & $9.39(213)$ & $2.07(193)$ & $-16.3(189)$ \\
\hline Total population & $-4.27(1100)$ & $-7.88(1053)$ & $-2.37(970)$ & $-13.9(947)$ \\
\hline
\end{tabular}

Tab. 3. Size class specific population changes in Kagekanu permanent vegetation plot

\begin{tabular}{|c|c|c|c|c|c|c|c|c|}
\hline Size & Pop 2008 & Pop 2009 & Pop 2010 & Pop 2011 & Change 08-09 & Change 09-10 & Change 10-11 & Change 08-11 \\
\hline 4.99 & 293 & 236 & 182 & 142 & -19.45 & -22.88 & -21.97 & -51.53 \\
\hline 9.99 & 397 & 382 & 346 & 331 & -3.77 & -9.42 & -4.33 & -16.62 \\
\hline 14.99 & 215 & 225 & 223 & 242 & 4.65 & -0.88 & 8.52 & 12.55 \\
\hline 19.99 & 43 & 60 & 69 & 71 & 39.53 & 15.0 & 2.89 & 65.11 \\
\hline 24.99 & 29 & 27 & 32 & 36 & -6.89 & 18.51 & 12.5 & 24.13 \\
\hline 29.99 & 31 & 24 & 20 & 28 & -22.58 & -16.66 & 40.0 & -9.67 \\
\hline 34.99 & 32 & 36 & 32 & 31 & 12.5 & -11.11 & -3.12 & -3.12 \\
\hline 39.99 & 22 & 23 & 23 & 22 & 4.54 & 0.0 & -4.34 & 0.0 \\
\hline 44.99 & 12 & 13 & 15 & 13 & 8.33 & 15.38 & -13.33 & 8.33 \\
\hline 49.99 & 15 & 14 & 12 & 15 & -6.66 & -14.28 & 25.0 & 0.0 \\
\hline 54.99 & 9 & 11 & 14 & 14 & 22.22 & 27.27 & 0 & 55.55 \\
\hline 59.99 & 2 & 2 & 2 & 2 & 0 & 0 & 0 & 0 \\
\hline
\end{tabular}


304

dbh was $6.06 \pm 2.02 \%$ and for the stems $>30 \mathrm{~cm}$ it was $2.05 \pm 2.06 \%$. There was no recruitment observed during the study period into $1 \mathrm{~cm}$ dbh class.

Growth and carbon sequestration

Mean growth rate in Avicinnia officinalis was found to be $0.6 \pm 1.08 \mathrm{~cm}$ per annum, with maximum growth of 3.71 $\mathrm{cm}$ and shrinkage of $3.2 \mathrm{~cm}$. It was $0.43 \pm 0.44 \mathrm{~cm}$ in Kandelia kandel, which had the maximum growth of $6.5 \mathrm{~cm}$ and shrinkage of $0.9 \mathrm{~cm}$. Mean growth rate in Rhizophora mucronata was $0.49 \pm 0.76 \mathrm{~cm}$, with growth as high as $9.1 \mathrm{~cm}$ and shrinkage of $1.2 \mathrm{~cm}$. Sonnaratia alba recorded a mean growth of $0.45 \pm 0.62 \mathrm{~cm}$, with maximum growth of $2.8 \mathrm{~cm}$ and shrinkage of $3 \mathrm{~cm}$. There was high variability in growth rates among species.

There was no pattern in growth rates in each species across different size classes (Tab. 4). However, there was high variability in mean growth rates in each size class (Tab. $4)$. The mean growth rates among different species in the size class $0-5 \mathrm{~cm}$ dbh were not significant ( $t$ test, $p>0.05$, NS). Mean growth rate of Avicinnia officinalis with other species in the size $5-10 \mathrm{~cm}$ dbh was significantly different $(\mathrm{t}$ test, $\mathrm{p}<0.05)$ and also between Kandelia kandel and Rhizophora mucronata ( $\mathrm{t}$ test, $\mathrm{p}<0.05$ ). Growth rate of Sonnaratia alba with Kandelia kandel and Rbizophora mucronata was not different ( $\mathrm{t}$ test, $\mathrm{p}>0.05$, NS). Among the stems of $10-15 \mathrm{~cm}$ dbh, Kandelia kandel had significant difference with Rhizophora mucronata and Avicinnia officinalis ( $\mathrm{t}$ test, $\mathrm{p}<0.05$ ), but rest of the combinations were not significant ( $t$ test, $\mathrm{p}>0.05$, NS).

There was a net gain of $1.36 \mathrm{~m}^{2}(5.57 \%)$ of basal area during the study period of three years. However, the gain was not uniform. During the first year, it was $0.56 \mathrm{~m}^{2}$ $(2.31 \%)$, in the second year it was negligible $\left(0.0014 \mathrm{~m}^{2}\right.$, $0.005 \%)$ and in the third year there was a significant gain of $0.79 \mathrm{~m}^{2}$ (3.18\%) (Tab. 5). Kandelia kandel lost $12.7 \%$ basal area during the study period, while other species gained basal area in the range of 5-6\%.

During the study period, in all censuses Avicinnia officinalis contributed with over $75 \%$ to the AGB pool, followed by Rhizhophora mucronata (10\%), Sonnaratia alba (8\%) and Kandelia kandel (2\%). AGB changed from 155.53 tons/ha to 164.28 tons/ha, resulting in a net accumulation of 8.76 tons. Avicinnia officinalis (8.61 tons) and Sonnaratia alba (1.41 tons) gained biomass, while both Kandelia kandel (1.25 tons) and Rizhophora mucronata (0.01 tons) lost biomass.

The carbon stock of the plot ranged from 77.7 to 82.1 tons of C. There was a net gain of 4.38 tons during the study period. The mean annual increment in $\mathrm{C}$ stocks over three years was $1.46 \pm 1.02$ tons. However, there is a great variability for this parameter. In the Kagekanu plot, large amount of carbon has been locked up in Avicinnia officinalis and accounts for more than $70 \%$ of total C stocks. Aviccinia officinalis also contributes significantly for the sequestration of C.

\section{Discussion and conclusions}

Mangroves are unique ecosystems of the world with adaptations to halophytic conditions. Mangrove ecosystems are known to provide great services to both human beings and others organisms, including fishes and water birds (Ewel et al., 1998; Bridgewater and Cresswell, 1999; Badola and Hussain, 2005; Donato et al., 2011). But mangrove forests are facing serious threat as a consequence of human activity (Valiela et al., 2001; Upadhyay et al., 2002).

Mangrove forests across the globe consists of species poor compared to either aseasonal rain forests or tropical dry forests (Condit, 1998). Mangrove forest of Kagekanu is also species poor. Pattern is similar to species richness reported from other mangrove patches along the western coast of India (Suresh et al., 2010). Less number of species was observed in pure mangrove stands off the coast of French Guiana (Fromard et al., 1998). Avicinnia officinalis dominates the floristics of Kagekanu plot. Similar pattern of dominance of Avicinnia sp. was also observed in Sundarbans (Joshi and Ghose, 2003), but domination of different species of Avicinnia was determined by salinity (Joshi and Ghose, 2003). Dominance of Avicinnia was also seen in pure stands of French Guiana (Fromard et al., 1998).

Tab. 4. Mean growth rates $( \pm S D)(\mathrm{cm})$ in various size classes for different species in Kagekanu permanent vegetation plot

\begin{tabular}{ccccc}
\hline Size class $(\mathrm{dbh} \mathrm{cm})$ & Avicinnia officinalis & Kandelia kandel & Rhizophora mucronata & Sonnaratia alba \\
\hline $0-4.99$ & $0.49 \pm 0.44$ & $0.54 \pm 0.70$ & $0.52 \pm 0.84$ & $0.53 \pm 0.49$ \\
$5-9.99$ & $0.80 \pm 0.70$ & $0.32 \pm 0.39$ & $0.43 \pm 0.44$ & $0.41 \pm 0.52$ \\
$10-14.99$ & $0.86 \pm 1.07$ & $0.28 \pm 0.33$ & $0.55 \pm 0.58$ & $0.49 \pm 0.31$ \\
$15-19.99$ & $0.68 \pm 1.19$ & $1.43 \pm 2.24$ & $0.66 \pm 0.79$ & $0.52 \pm 0.65$ \\
$20-24.99$ & $0.66 \pm 0.74$ & $0.26 \pm 1.53$ & $1.64 \pm 4.36$ & $0.34 \pm 0.34$ \\
$25-29.99$ & $0.40 \pm 0.57$ & $\mathrm{NA}$ & $0.04 \pm 0.03$ & $-3.77 \pm 5.72$ \\
$30-34.99$ & $0.3 \pm 0.41$ & $\mathrm{NA}$ & $0.70 \pm 0.43$ & $1.36 \pm 1.84$ \\
$35-39.99$ & $0.52 \pm 0.58$ & $\mathrm{NA}$ & $0.40 \pm 0.21$ & $\mathrm{NA}$ \\
$40-44.99$ & $0.86 \pm 0.95$ & $\mathrm{NA}$ & $\mathrm{NA}$ & $\mathrm{NA}$ \\
$45-49.99$ & $0.50 \pm 0.71$ & $\mathrm{NA}$ & $\mathrm{NA}$ & $\mathrm{NA}$ \\
$50-54.99$ & $0.31 \pm 0.84$ & $\mathrm{NA}$ & $\mathrm{NA}$ & $\mathrm{NA}$ \\
$55-59.99$ & $0.29 \pm 0.03$ & $\mathrm{NA}$ & $\mathrm{NA}$ & $\mathrm{NA}$ \\
\hline
\end{tabular}

Tab. 5. Basal area changes (\%) in the Kagekanu permanent vegetation plot

\begin{tabular}{cccccc}
\hline Year & Size $0-10 \mathrm{~cm} \mathrm{dbh}$ & Size $10-20 \mathrm{~cm} \mathrm{dbh}$ & Size $20-30 \mathrm{~cm} \mathrm{dbh}$ & Size $>30 \mathrm{~cm} \mathrm{dbh}$ \\
\hline $2008-2009$ & -4.98 & 19.09 & -14.44 & 8.91 & -0.57 \\
$2009-2010$ & -9.83 & 4.60 & 4.14 & -0.08 \\
$2010-2011$ & -5.81 & 4.21 & 13.76 & 1.38 & 2.80 \\
\hline
\end{tabular}


However, Jayatissa et al. (2002) reported 8-16 true mangrove species from different patches at Sri Lanka. The complexity index of Kagekanu plot (6) is considerably low compared to mature mangrove stands of French Guiana (18, Fromard et al., 1998), which could be attributed to the height of the forest. Mean height of Kagekau plot was 5.58 meters, while in French Guiana it was 19.6 meters. Total number of species recorded in Indian mangroves is 33 (Selvam, 2003). Region-wise diversity of mangrove species, which include both true and associated species in India, is given in Mandal and Naskar (2008). A total of 13 species was reported from mangrove forests of Godavari region (Azariah et al., 1992).

Azriah et al. (1992) also reported a gradient in species diversity, with inland mangroves being highly diverse. Relative mangrove diversity of Kagekanu region, as estimated by Mandal and Naskar (2008), is also low compared with other mangrove regions in India. Kagekanu plot, being a shoreline mangrove, is having a low species diversity, which could be attributed to high salinity.

Size class distribution of individuals followed the typical inverted "J" shaped curve, which is seen in most tropical (Sukumar et al., 1992) and other mangrove forest patches (Jimenez et al., 1991; Cox and Allen, 1999; Khan et al.; 2009). A bell shaped curve is reported for Rhizophora plantation from Kenya (Kairo et al., 2008) and for natural Rhizophora forest of Malaysia (Eong et al., 1995). Density of stems at Kagekanu plot was considerably low compared to stands in Odisha (Upadyay and Mishra, 2008). Kairo et al., (2008) reports a density of 5132 individuals in a hectare of 12 year old Rhizophora plantation. Similarly, Engo et al. (1991) reports a stand density of little over 4000 stems from Malaysia. Exceptionally high density of 47000 stems over $2.5 \mathrm{~cm}$ dbh was recorded in mangrove stands of Puerto Rico (Pool et al., 1977).

There is a great variation in basal area reported for mangrove forests across tropics. Pool et al. (1977) reports an area as high as $96.4 \mathrm{~m}^{2} /$ ha to as low as $6.0 \mathrm{~m}^{2} /$ ha from Central America. Komiyama et al. (2008) reports values ranging from $2.5 \mathrm{~m}^{2} /$ ha to $43.8 \mathrm{~m}^{2} /$ ha for mangrove forest patches across globe. Basal area of Kagekanu plot is in the range of values reported for tropical dry forest (Sukumar et al., 1998) and is higher than the values reported from Sundarbans (Joshi and Ghosh, 2003).

Mangrove forests are dynamic systems. The dynamism in these forests is influenced both by extreme natural events such as hurricane, cyclone and tsunami, as well as normal processes including diseases and pests, resulting in natural mortality and recruitment (Jamenez et al., 1985).

Other human mediated factors, such as erosion and flooding, could also result in mangrove tree mortality (Jamenez et al., 1985). Kagekanu plot is not exposed to any of the natural extreme events. Our results indicate the decline in total population as shown in dry forests of Mudumalai initially (Sukumar et al., 2005). However, longterm data is required to understand the dynamics of a forest. Mortality rates reported in the literature (Jamenez et al., $1985)$ include small seedlings. Hence, the rates observed in Kagekanu are not comparable. There are hardly any studies on the dynamics of mangrove forest as they are done in either dry or moist land forests (Losos and Leigh, 2004).

\section{Carbon sequestration potential}

Mangrove forests are one of the carbon rich forests in the tropics (Donato et al., 2011), however most carbon is locked up in the soil. There is a great variation in AGB across different geographical areas. AGB of mangrove forest at a global scale varies from as low as 7.9 tons/ha to as high as 460 tons/ha (Fromard et al., 1998; Komiyama et al., 2008; Khan et al., 2009). One hectare of mangrove forest in Kagekanu plot has 155.53 tons, which is in the range of values reported for other forests, such as tropical dry forests (Sukumar et al. unpublished results), mangrove forest patches in Andaman islands (Mall et al., 1991), Rhizophora plantations in Kenya (Kairo et al., 2008) and mangrove patches in French Guiana (Fromard et al., 1998). There is also a considerable variation in biomass storage across species, along with total biomass. At Kagekanu plot, Avicinnia officinalis accounts for $>70 \%$ of total biomass. Sonnaratia alba in Kagekanu plot accounts for $8 \%$ of biomass, while Sonnaratia apetala has significant amount of biomass in Sundarban mangroves (Mitra et al., 2011). A detailed analysis of carbon content in different forests across different districts in India has been carried out (Chhabra $e t$ al., 2002). According to them, India had a total phytomass C pool of $3874.3 \mathrm{TgC}$ in 1994. According to Ravindrnath et al. (2008) total forest carbon stocks in India was 10.01 GtC. Chhabra and Dadhwal (2004) based on growing stock-volume approach, estimated the Indian forest phytomass in the range of 3.8-4.3 PgC. A hectare of mature forest such as Kagekanu is estimated to sequester 1.46 tons of carbon per annum, which is higher than the reported value of 0.535 tons/ha (Lal and Singh, 2000). The above ground carbon sequestration rate is comparatively lower than most forest types in the world; most forest are reported to sequester carbon in the range of 1.40 to 8 tons/ha (Jina $e t$ al. 2008). A hectare of Rhizophora plantation is estimated to accumulate 11.0 tons (equivalent to $5.5 \mathrm{tC}$ ) (Kairo et al. 2008). Putz and Chan (1986) record mean increment of 6.7 tons/ha/year of biomass in mangrove forest of Malaysia. India has 306400 hectares of mature (dense) and moderately dense mangrove stand (FSI, 2011). Assuming the above values, mature stands of Indian mangroves sequester 447,344 tons of $\mathrm{C}$ per annum. These values are comparatively low with other mangrove stands across the globe. Dense mangroves form $0.44 \%$ of total forest cover. Degraded mangroves cover an area of 157500 hectares. Reclamation of these mangroves and development into dense mangroves would result in additional 229,950 tons of carbon per annum. Total carbon sequestered by above ground mangrove vegetation would be 677,294 tons per annum. Contribution of mangrove forests to the total carbon pool of the country is on the lower side, as mangrove forests cover relatively less geographical area. But we need to have a pragmatic approach to conservation and development of mangrove forests, as they store very high levels of soil carbon, and also offer immense ecosystem services. Therefore, there is an urgent need to make a proper assessment of potential area available for the development of mangrove vegetation through assisted propagation and planting of mangrove species along traditional coastal agricultural bunds, which would help in not only mitigation of impacts of climate change, but also provide several 
306

ecosystem services to communities that are traditionally dependent on mangroves.

\section{Acknowledgements}

We thank Ministry of Environment and Forests, Government of India for funding this research. We thank Forest department, Karnataka State for their help during the research. We thank Sridhar Patagar, M. Govinda Praveen Dube, Mr. Deepak Shetty, Mr. G.T. Hegde and other for their help during the field survey. We thank the Kagekanu temple authorities for their help and cooperation.

\section{References}

Azariah JH, Azariah S, Gunasekaran, Selvam V (1992). Structure and species distribution in Coringa mangrove forest, Godavari Delta, Andhra Pradesh, India. Hydrobiologia 247:11-16.

Badola R, Hussain SA (2005). Valuing ecosystem functions: an empirical study on the storm protection function of Bhitarkanika mangrove ecosystem, India. Environ Conservat 32:85-92.

Bhat DM, Hegde GT, Shetti DM, Patgar SG, Hegde GN, Furtado RM, Shastri CM, Bhat PR, Ravindranath NH (2011). Impact of disturbance on compositrion, structure and floristics of tropical moist forests in Uttara Kannada district, Western Ghats, India. Ecotropica 17:1-14.

Bridgewater PB, Cresswell ID. (1999). Biogeography of mangrove and saltmarsh vegetation: implications for conservation and management in Australia. Mangroves and Salt Marshes 3:117-125.

Brown S, Gillespie A, Lugo AE. (1989). Biomass estimation methods for tropical forests with application to forest inventory data. For Sci 35:881-902.

Chave J, Andalo C, Brown S, Cairns MA, Chambers JQ, Eamus D, Folster H, Fromard F, Higuchi N, Kira T, Lescure J-P, Nelson BW, Ogawa H, Puig H, Riera B, Yamakura $\mathrm{T}$ (2005). Tree allometry and improved estimation of carbon stocks and balance in tropical forests. Oecologia 145: 87-99.

Chatutvedi RK, Tiwari R, Ravindranath NH (2008). Climate change and forests in India. Intern Fores Rev 256-268.

Chhabra A, Palria S, Dadhwal VK. (2002). Spatial distribution of phytomass carbon in Indian forests. Global Chan Biol 8:1230-1239.

Condit R (1998). Tropical forest census plots. Springer-Verlag.

Cox EF, Allen JA. (1999). Stand structure and productivity of the introduced Rhizophora mangle in Hawaii. Estuaries. 22:276-284.

Daniels RJR (1989). Conservation strategy for the birds of the Uttara Kannada district. PhD Thesis submitted to Indian Instit Sci Bangal.

Donato DC, Kauffman JB, Murdiyarso D, Kurnianto S, Stidham M, Kanninen M (2011). Mangroves among the most carbon-rich forests in the tropics. Nature Geoscience 4(5):293-297.
Duke NC, Ball MC, Ellison JC (1998). Factors influencing biodiversity and distributional gradients in Mangroves. Global Ecol Biogeog Letters 7:27-47.

Ewel KC, Zheng S, Pinzon ZS, Bourgeois JA (1998). Environmental effects of canopy gap formation in highrainfall mangrove forests. Biotropica 30:510-518.

Forest Research Institute and Colleges, Dehradun (1970). Growth and yield statistics of common Indian timber species. Volume II. Forest Research Institute and colleges. DehraDun. India.

Forest Survey of India (2011). State of Forest Report (2011). Forest Survey of India. Ministry of Environment and Forests. DehraDun. India.

Fromard F, Puig H, Mougin E, Marty G, Betoulle JL, Cadamuro L (1998). Structure, above-ground biomass and dynamics of mangrove ecosystems: new data from French Guiana. Oecologia 115:39-53.

Gadgil M, Berkes F, Folke C (1993). Indigenous knowledge for biodiversity conservation. Ambio 22:151-156.

Giri C, Zhu Z, Tieszen LL, Singh A, Gillette S, Kelmelis JA (2008). Mangrove forest distributions and dynamics (1975-2005) of the tsunami-affetced region of Asia. J Biogeog 35:519-528.

Gopal B, Sah M (1995), Inventory and classification of wetlands in India. Vegetatio 118:39-48.

Gopal B, Chauhan M (2006). Biodiversity and its conservation in the Sundarban mangrove ecosystem. Aqua Sci 68:338354.

Haripriya GS (2003). Carbon Budget of the Indian Forest ecosystem. Climate Change 56:291-319.

Jana BK, Biswas S, Majumdar M, Roy PK, Majumdar A. (2009). Carbon sequestrtation rate and above ground biomass carbon potential of four young species. J Ecoland Natural Environ 2:15-24.

Jayatissa LP, Dahdouh-Guebas F, Koedam N (2002). A review of the floral composition and distribution o mangroves in Sri Lanka. Biol J Linn Soci 138:29-43.

Jimenez JA, Lugo AE (1985). Tree mortality in mangrove forests. Biotropica17:177-185.

Jina BS, Sah P, Bhatt MD, Rawat YS (2008). Estimating carbon sequestration rates nad total carbon stockpilein degraded and non-degrade sites of oak and pine forest of Kumaun central Himalaya. Ecoprint 15:75-81.

Joshi H, Ghose M (2003). Forest structure and species composition along soil salinity and $\mathrm{pH}$ gradient in mangrove swamps of the Sundarbans. Tropical Ecology 44(2):195-204.

Kairo JG, Lang'at JKS, Dahbouh-Guebas F, Bosire J, Karachi M (2008). Structural development and productivity of replanted mangrove plantations in Kenya. Fores Ecoland Managemen 255:2670-2677.

Khan MNI, Suwa R, Hagihara A (2009). Biomass and above ground net primary production in a subtropical mangrove stand of Kandelia obovata (S.L.) Yong at Manko wetland Oknawa, Japan. Wetlands Ecology Managem 17:585-599. 
Komiyama A, Ong JE, Poungparn S (2008). Allometry, Biomass, and productivity of mangrove forests: A review. Aquatic Bot 89:128-137.

Kumar IJN, Sajish PR, Rita NK, Basil G, Shailendra V (2011). Nutrient dynamics in an Avicennia marina (Forsk.) Vierh. Mangrove forest in Vamleshwar, Gujarat, India. Not Sci Biol 3:51-56.

McShea WJ, Davies SJ, Bhumpakphan N (2011). The ecology and conservation of seasonally dry forests in Asia. (Eds.) Smithsonian Institution Scholarly Press. Washington DC, USA.

Lal M, Singh R (2000). Carbon sequestration potential of Indian forests. Environ Monit Assess 60:315-327.

Lee HS, Davies SJ, LaFrankie JV, Tan S, Itoh A, Yamakura T, Okhubo T, Ashton PS (2002). Floristic and structural diversity of 52 hectares of mixed dipterocarp forest in Lambir Hills National Park, Sarawak, Malaysia. J Trop Forest Sci 14(3):379-400.

Leigh E, Losos E (2004). The Global Network of Large Forest plots. University of Chicago Press, Chicago, USA

Lugo AE, Snedakar SC (1974). The Ecology of Mangroves. Ann Rev Ecol System 5:39-64.

Lugo AE, Brown S, Brinson MM (1990). Concepts in wetland ecology. Pp 53-85. In: Lugo AE, Brinson MM, Brown S (eds.), Ecosystems of the world 15, Forested wetlands. Elsevier, Amsterdam.

Mall LP, Singh VP, Garge A (1991). Study of biomass, litter fall, litter decomposition and soil respiration in monogeneric mangrove and mixed mangrove forests of Andaman Islands. Trop Ecol. 32:144-152.

Mandal BN, Naskar KR (2008). Diversity and classification of Indian mangroves: a review. Trop Ecol 49:131-146.

Mitra A, Sengupta K, Banerjee K (2011). Standing biomass and carbon storage of above-ground structures in dominant mangrove trees in the Sundarbans. Forest Ecol Manag 261:1325-1335.

Putz FE, Chan HT (1986) Tree growth, dynamics and productivity in a mature mangrove forest in Malaysia. Forest Ecol Manag 17:211-230.

Ravindranath N H, Somashekar BS, Gadgil M (1997). Carbon flows in Indian forests. Climate Change 35:297-320.
Ravindranath N H, Chaturvedi RK, Murthy IK (2008). Forest conservation, afforestation and reforestation in India: Implications for forest carbon stocks. Current Sci 95:216222.

Ravindranath N H, Murthy IK (2010). Greening India Mission. Current Sci 99:444-449.

Selvam V (2003). Environmental classification of mangrove wetlands of India. Current Sci 84:757-765.

Singh VP, George A, Pathak SM, Mall LP (1987). Pattern and process in mangrove forests of the Andaman Islands. Vegetatio 71:85-188.

Sukumar R, Dattaraja HS, Suresh HS, Radhakrishnan J, Vasudeva R, Nirmala S, Joshi NV (1992). Long term monitoring of vegetation in a tropical deciduous forest in Mudumalai, southern India. Current Sci 62:608-616.

Sukumar R, Suresh HS, Dattaraja HS, Joshi NV (1998). Dynamics of a tropical deciduous forest: Population changes (1988 through 1993) in a 50-hectare plot at Mudumalai, southern India. In: Dallmeier F, Comiskey JA (eds.), Forest Biodiversity Research, Monitoring and Modelling: Conceptual Background and Old World Case Studies. UNESCO, Paris and The Parthenon Publishing Group, Man and The Biosphere Series, Volume 20, Chapter 28, p. 495-506.

Suresh HS, Bhat DM, Ravindranath NH, Sukumar R (2010). Structure and diversity of Mangrove forest patches along coast of Karnataka. In Zoological Surv. India. Mangroves in India: Biod, Protection Environ Serv 185-191.

Tomlinson PB (1986). The Botany of Mangroves. Cambridge University Press. Cambridge.

Upadhyay VP, Ranjan R, Singh JS (2002). Human-mangrove conflicts: The way out. Current Sci 83:1328-1336.

Upadhyay VP, Mishra PK (2008). Population status of mangrove species in estuarine regions of Orissa coast, India. Trop Ecol 49:183-188.

Valiela I, Bowen JL, York JK (2001). Mangrove forests: one of the world's threatened major tropical environments. Bioscience 51:807-815.

WB (The World Bank) (1998). A practical guidance document for the assessment of project level greenhouse gas emissions. Greenhouse gas assessment handbook. World Bank 64:168. 